Nemanja Veselinović ${ }^{1}$

P. $19-28$

University of Niš

Faculty of Economics

SCIENTIFIC REVIEW ARTICLE

Received: February, 22, 2019

Martina Veselinović ${ }^{2}$

Accepted: April, 15, 2019

University of Belgrade

Faculty of Organizational Sciences

\title{
TECHNOLOGICAL INNOVATION IN THE PETROLEUM INDUSTRY - THE CASE OF NIS J.S.C. NOVI SAD
}

\begin{abstract}
The petroleum companies strive to develop continuous technological innovation with the aim to gain a competitive advantage. Technological trends and their effects on the business of the company NIS j.s.c. Novi Sad will be presented in this paper. NIS j.s.c. Novi Sad stands for one of the leading vertically integrated energy companies in Southeast Europe. The subject of the paper is the observation of technological trends of the company NIS j.s.c. Novi Sad with a special view on innovation of the company NIS j.s.c. The aim of the paper is to identify characteristics, importance and reach of the designed and implemented technological innovations of the company NIS j.s.c. Novi Sad, and to propose directions which the company should take into account while making future strategic moves. The case study method will be used in this paper as research methodology.
\end{abstract}

Key words: technological innnovation, petroleum industry, competitive advantage

JEL classification: 032

\section{ТЕХНОЛОШКЕ ИНОВАЦИЈЕ У НАФТНОЈ ИНДУСТРИЈИ - СЛУЧАЈ НИС А.Д. НОВИ САД}

\begin{abstract}
Апстракт
Нафтне компаније настоје да развијају континуиране технолошке иновације у цииљу стицања конкурентске предности. Технолошки трендови и њихови ефекти на пословање компаније НИС а.д. Нови Сад ће бити представљени у овом раду. НИС а.д. Нови Сад представља једну од водећих вертикално интегрисаних енергетских компанија у југоисточној Европи. Предмет рада је праћење технолошких трендова компаније НИС а.д. Нови Сад са посебним освртом на иноваиије компаније НИС а.д. Нови Сад. Циљ рада је да идентификује карактеристике, значај и досег пројектованих и имплементираних технолошких иновација компаније НИС а.д. Нови Сад, као и да предложи правие које компанија
\end{abstract}

\footnotetext{
${ }^{1}$ nemanjaveselinovic@gmail.com

${ }^{2}$ martinaveselinovic@gmail.com
} 
треба да узме у обзир приликом прављења будућих стратешких потеза. Метод студија случаја ће се користити у овом раду као методологија истраживања.

\section{Кључне речи: технолошке иновачије, нафтна индустрија, компетитивна предност}

\section{Introduction}

The entire history of the petroleum industry could be described as very challenging, as adaptation and innovation were the main drivers of the petroleum industry development. Firstly, most of the largest private petroleum companies established a downstream business - refining oil products. Afterwards, they started steadily to get into upstream activities, such as exploration and production, with a desire to diversify their products and diminish the risk of price and supplies instability. Openness to innovation and state-of-the-art technology have always been present in the petroleum industry. Technological development has continuously been affecting all stages, from upstream to downstream activities.

Oil and gas companies are developing and implementing new technologies to boost their efficiency and competitiveness, which results in gaining higher returns. Moreover, they are investing in different products, such as renewables and hydrogen. Companies are supporting the energy shift to a greener, cleaner use of energy. The proportion of green products of oil and gas companies is still small because their commercial success is less tenable. The petroleum industry is not in the collision with neither the advent of renewables nor global emissions restraint. Also, oil and gas companies operate by the specific electrified transportation and the current pattern of energy use and demand.

The pressure for advanced technologies is continuous, and the chances for further development are enormous. On the one hand, the key industry players will adapt and survive, while, on the other hand, smaller players should use their chances on the market since there are new niches opening up. These industry players should utilize and make the most of technological innovations with the aim to become greener and more flexible. Advanced technologies are forming the industry's main activities, connecting closely not only old and new methods, but also products. Also, they allow the use of previously inaccessible resources, and their presence results in improvements in efficiency and productivity. Another positive effect is the reduced impact of operations and products on the environment.

Technological innovation and their effects on the business of the company NIS j.s.c. Novi Sad will be presented in this paper. NIS j.s.c. Novi Sad stands for one of the leading vertically integrated energy companies in Southeast Europe. The subject of the paper is the observation of technological trends of the company NIS j.s.c. Novi Sad with a special view on innovation of the company NIS j.s.c. The aim of the paper is to identify characteristics, importance and reach of the designed and implemented technological innovations of the company NIS j.s.c. Novi Sad, and to propose directions which the company should take into account while making future strategic moves. Main questions in this paper are: what is innovation, what is the typology of innovation, which technological innovations are developed in this company, which effects these technological innovations and development have on the business of the company, are technological innovations necessary to make progress in the petroleum industry. The case study method will be used in this paper as research methodology. 


\section{Theoretical background}

Technological trends come from different innovations which enable higher productivity, efficiency and profit. It is necessary to conduct continuous innovations in the petroleum industry in order to be competitive in the market. So, it is imperative to start with the concept of innovation. The word innovation is originally derived from the Latin noun innovatus and appears for the first time in print in the fifteenth century. Innovation can be defined as new combinations of new or existing knowledge, resources, equipment, and other factors (Schumpeter, 1934). Also, Drucker (1985) describes innovation as the specific entrepreneural instrument, which entrepreneurs exploit as an opportunity for a dissimilar business or service.

There are different typologies of innovation in the literature. Schumpeter (1934) recognized five types of innovation:

1. new products,

2. new production methods,

3. exploitation of new markets,

4. new ways to offer products and

5. new ways of business organization.

To classify innovations, certain criteria could be used, such as the nature of innovation and the type of innovation (Stošić, 2013). A vital attribute of every innovation, the degree of novelty, depends on such criteria. According to the criterion of the nature of innovation, there are two broad types of innovation: radical and incremental innovations (Stošić, 2013). Incremental innovations are small improvements, while radical innovations require new products, services, processes etc. Moreover, incremental innovations are a result of constant improvements to products and processes, while radical innovations are based on new concepts, which strive to technological revolutions and a significant economic influence.

According to the same criterion, OECD classifies following types of innovation (Stošić, 2013):

1. application of scientific breakthrough,

2. essential technical innovation,

3. technical improvement or change,

4. transfer technique to another sector,

5. adaptation of the existing product to the new market.

According to the criterion of the type of innovation, there are two types of innovation (Stošić, 2013): product/service innovation and process innovation. According to the same criterion, OECD classifies following types of innovation (sub-criteria - technical variables):

1. product innovation - use of new materials, use of new intermediates, new functional parts, new features,

2. process innovation - new production techniques, a higher degree of automation, new organization (with regard to new technologies).

According to the same criterion, OECD classifies following types of innovation (subcriterion - the market) (Stošić, 2013):

1. novelty for the world or national economy,

2. novelty for the company.

Some types of innovation from the field of management are product innovation, process 
innovation, organizational innovation, management innovation, production innovation, commercial innovation and service innovation (Trott, 2017; Stošić, 2013). Schmookler (1966) made the difference between technological product and technological production by defining how to create, improve and produce products. Likewise, product innovation and process innovation were mentioned as types of technological innovations in the Oslo Manual (2005). Levi - Jakšić, Marinković and Obradović (2005) note that technological innovations consist of technological product innovation and technological process innovation. They also mention technological innovation in the area of information technology.

Technological innovation can be defined as conceiving and producing "a new solution to a real or perceived need (invention)", as developing "this solution into a viable and producible entity (realization)", as successfully introducing and supplying "this entity to the real or perceived need (implementation)" (Mentz, 1999). So, product technological innovation could be the outcome of production and commercialization of new products/ services or improved products/services. Process technological innovation refers to the use or adoption of a new production process or an improved production process. It is recommended that all companies should develop both types of innovations at the same time, with the aim of increasing price and technological competitiveness. Certainly, all innovations must have a particular degree of novelty, both technological and non-technological innovations.

The essence of innovation is the necessity of linking the technical capabilities and the needs of the market (Levi - Jakšić, Marinković \& Obradović, 2005). It is necessary to determine the needs of the market and the technical assets that can satisfy these needs. Since there is a strong correlation between market performance and new products, innovations contribute to the business in multiple ways: by capturing and retaining market shares, increasing profitability and sales growth and so on (Tid, Bessant \& Pavitt, 1997). New products are a good indicator of a substantial capability because the environment has the feature to frequently change (Tid, Bessant \& Pavitt, 1997). This could confirm that the longterm trend for continuous innovations is obligatory for all companies worldwide, which want to retain the market share and penetrate the market. Every company depends on its results, and with the help of technological innovations companies can achieve different kinds of results, such as financial, environmental, etc.

According to the Oslo Manual, firms can eco-innovate by acquiring and implementing cleaner, greener technologies. So special attention is given to innovations regarding their contribution to environmental performance. In many countries, ecoinnovation is regarded as a very significant factor which helps to solve environmental problems, including climatic, energy and natural resource security issues (Diaconu, 2011). Eco-innovation can be considered as a potential source of competitive advantage for companies on the market (Diaconu, 2011). This term refers to a more favorable ecological influence of production processes or the use of goods. Other terms could also be used for eco-innovation, such as: "environmental innovation", "innovation for sustainable development" or "sustainable innovation" (Diaconu, 2011). The concept of eco-innovation is connected with diverse concepts, such as eco-efficiency, cleaner production methods, and eco-design (Diaconu, 2011).

However, eco-innovation can be expressed as 1) the decrease of environmental risks, pollution and resource consumption; 2) goods, manufacturing processes or business models; 3) green technologies; 4) radical and systemic or incremental (Diaconu, 2011). Technological eco-innovations refer to products or processes which contribute to the betterment of 
environmental conditions by incorporating technological progress. Also, they can be analyzed by using mechanisms and impacts these products and processes make. Considering mechanisms, technological eco-innovations are: 1) small and stable changes to products or processes; 2) re-designing, by making substantial changes of the existing products or processes; 3) using alternatives with the same functional characteristics, but which operate as replacements of existing products; 4) creating, designing and introducing of new products or processes (Diaconu, 2011).

\section{Research methodology}

To analyze the current technological innovations of the company NIS j.s.c. Novi Sad, online research has been conducted. All data gathered from the website of the company and annual reports will be presented through one method: case study method.

Case study method is well established in social sciences. It could provide information in the practice what has worked well, what has been attained and what have been main questions and problems. It is necessary to examine a real-life current phenomenon with this kind of research methodology. It is recommended to use several sources of evidence (Yin, 2009). Also, it is very hard to come to generalizing conclusions and has been often criticized when you use only one case study in research (Tellis, 1997). It was discussed that the relative size of the sample used does not convert a single or manifold case into a macroscopic study (Hamel et al., 1993; Yin, 2009). The single case could be regarded as satisfactory, in case of achieving established objectives for the study. Results of single case studies could not be statistically generalizable, but could be analytically generalizable (Welsh \& Lyons, 2001).

\section{Main research}

As previously mentioned, the subject of the paper is the observation of technological trends of the company NIS j.s.c. Novi Sad. NIS provides the energy for making progress to the people of the Balkan region, by using responsibly natural resources and latest technology. Innovations are the basis of the business philosophy of NIS, and they are especially expressed through the application of new and clean technologies, which is in accordance with the leading position in guarding the environment. On the road of transformation from a typical oil and gas company into a comprehensive energy system, NIS has invested more than 15 million euros which make them the leader in investment and innovation in Serbia.

This research is based on information gathered on the Internet, from the company's website and annual reports. Also, the case study method was chosen as an appropriate method to present the results of the research. The petroleum industry is specific because of its vast impact on the environment, high costs of equipment, unstable prices, etc. Consequently, the idea of this research was to show which trends one big Southeastern oil and gas company follows and to propose directions which can enable oil and gas companies to be more profitable and eco-friendly. 


\section{Case study}

Aware of responsibility as only Serbia's oil and gas exploiter and extractor, NIS is led by innovations in daily operations and at the same time investing in new technologies and new production capacities. To ensure company's continuous growth and better living conditions in the environment, NIS is proactive in the implementation of technologically innovative projects:

1. Bottom of the Barrel Plant;

2. Cogeneration - mini-power plants and TE-TO Pančevo;

3. Amine Plant.

1. Bottom of the Barrel Plant - The construction of a deep processing plant with delayed coking technology is a crucial project for the second phase of modernization of the Oil Refinery in Pančevo. Bottom of the Barrel Plant represents one of the prime investments in Serbia in the following period, as the total volume of investments will amount to more than 300 million euros. New plants will start operating in the third quarter of 2019 when NIS refinery will produce more high-quality fuels, as well as coke, a product that has been imported to Serbia so far.

With the realization of the project "Bottom-of-the-Barrel", the oil refinery in Pančevo will be one of the most contemporary refineries in Eastern Europe. Also, after the construction and commissioning of new plants, optimal utilization of the refinery's capacity is expected and the efficiency of oil processing in NIS is expected to increase to $99.2 \%$ in 2019 from the currently $86 \%$.

This means that high-sulfur oil will cease, and at the other hand, the project will enable increasing of production of high-quality gasoline, liquid petroleum gas, diesel fuel and liquid petroleum gas, thus brighter petroleum products which are more eco-friendly. The structure of production of petroleum products on the new facility is expected to be: LPG will increase for $14 \%$, gasoline $12 \%$, heavy diesel $26 \%$, light diesel $27 \%$, coke $21 \%$. Regarding the rest of the production outcome, its average price before the project is $168 \mathrm{USD} / \mathrm{t}$ while expected average price after the project will be increased on $432 \mathrm{USD} / \mathrm{t}$. This shows that NIS will ensure higher EBITDA than in the current period. With higher EBITDA the company is going to get more investment funds for new ecology projects.

The basis of the whole process contains two reactors, in which the rest after heating is undergoing the coking process, with additional separation of white derivatives. After the coking process, the process of hydraulic cutting, drilling and unloading of coke into the transport and loading system is carried out. Also, the project predicts the construction and installation of equipment for cutting and drilling coke, transportation lines and distinct storage systems for coke.

By modernizing its refinery in Pančevo and using modern technologies, NIS will further improve environmental protection. The rudimentary ecological aspect of this project is the fact that NIS will finish with the production of masses with a high content of sulfur, which means that in the Serbian market there will be no fuels that in combustion cause the emission of significant amounts of sulfur compounds in the atmosphere. Thanks to the "Bottom-ofthe- Barrel" project, the ecological situation in the entire region will improve. As for the coke production technology itself, state-of-the-art technology solutions and technologies will be used to ensure careful treatment of the environment and the minimal use of energy resources.

The requirements of Directive 1999/32/EC on the reduction of sulfur content in certain 
liquid fuels will be met in that case also. It became the first energy plant in Serbia with the IPPC (International Plant Protection Convention) integrated permit, which confirms that the production process in the Refinery is fully aligned with European standards in the field of environmental protection. With the constant modernization of the Oil Refinery in Pančevo, NIS has enabled the production of European-quality fuel in Serbia, which contributes to the energy stability of the country. The implementation of the "Bottom-of-the-Barrel" project enables to NIS retaining the position of a regional leader in the petroleum product market and offering its customers more high-quality fuel.

The similar facilities in surroundings exist in Refinery Rijeka in Croatia where starting activities of production are planned for 2022. From the fact that NIS's starting date of production is scheduled for 2019, we can conclude that NIS can gain a competitive advantage.

2. Cogeneration - Cogeneration represents mini-power plants which boost the company's efficiency. NIS demonstrates its ecological responsibility, but also the increase in efficiency at work, by launching mini-power plants on petroleum fields in Serbia, which produce electricity that is sold on the Serbian and regional markets through low-quality gas. So far, NIS has built 14 mini power plants in oil fields in Serbia, with a total capacity of 14 MW, which is, for example, sufficient to supply 20,000 average households.

Cogeneration is based on the production of electricity and thermal energy from gas that was not previously used because it contains a high degree of carbon dioxide and nitrogen. The process of converting this gas into electricity has a particularly ecological dimension, as this reduces the emissions of harmful gases into the atmosphere since this gas was previously burnt on the flare. It is in line with the energy and contemporary environmental trends, regarding rationalizing energy consumption and reducing pollution. As NIS is, together with the Electric Power Industry of Serbia, the only producer of electricity in the free market in our country, increasing capacity in electricity production is a big step for all consumers in Serbia.

Also, NIS is constructing Power and Heating Plant (TE-TO) Pančevo. In the second quarter of 2018, the construction of a thermal power plant in Pančevo began, with a total power of $1400 \mathrm{GWh}$, which is sufficient for the annual supply of 230,000 households. The plant will function by using the gas-steam cycle, therefore also on the principle of cogeneration, which is the energy and ecologically best solution in the production of electricity from natural gas. TE-TO Pančevo will primarily produce electricity to meet the needs of the Pančevo Oil Refinery for technological steam and electricity, while a significant surplus of electricity will be distributed to the Serbian electric power system. TE-TO Pančevo represents combined gas-fired power plant with a combined production of electric and thermal energy. With the realization of the project TE-TO Pančevo, Serbia gets another guarantor of energy stability and security in the supply of electricity.

In October 2017, a contract was signed on the construction of a power plant with the Chinese company "Shanghai Electric Group". TE-TO Pančevo will start operating in the fourth quarter of 2019, and the investment in this facility will amount to more than 195 million dollars. The construction of the TE-TO Pančevo jointly is realized by the companies "Gazprom Energoholding", a specialized company (100\% daughter company of PJS Gazprom) for the management of Gazprom Group companies in the electricity and NIS. Also, NIS is planning the project named "Windpark" in municipality Plandište, which should be finished until April 2020. "Windpark" contains usage of wind energy to produce electricity. In this way, NIS shows usage of green technology. 
3. Amine Plant - As a company that follows the latest trends in the field of green energy and the use of renewable energy sources, in 2016, NIS launched the Amino Natural Gas Purification Plant, which uses less favorable gas for the production of high-quality energy for industrial and household use. The ecological significance of the Amine Plant is to prevent the release of carbon dioxide from natural gas into the atmosphere. The Amine Plant is intended to increase the quality of domestic natural gas, which is achieved by removing carbon dioxide and other gaseous substances, but at the same time, it affects the increase in production volume. The investment in the construction of this modern plant amounts to more than 30 million euros.

HiPACT (High-Pressure Acidgas Capture Technology) is the technology used in the Amine Plant. It is one of the most effective methods among the existing methods in the process of gas processing. The use of this technology enables the savings of heat and electricity, as well as consumables up to $25 \%$ compared to the technologies that were used earlier, which additionally increased the efficiency of the business. The plant works on the principle of treating natural gas with the amine, a chemical compound that effectively binds and removes impurities, such as carbon dioxide and hydrogen sulfide from natural gas. This means that carbon dioxide and other gas substances are extracted from domestic natural gas. The process of carbon dioxide separation is carried out in two phases: through amine washing, which involves the removal of acid gas, and drying during which the water is removed from natural gas.

In addition to increasing the quality and volume of natural gas production, the Amine Plant has a distinctive ecological significance. The process of processing in this plant is such that it completely prevents the carbon dioxide from reaching the atmosphere. This is achieved by not extracting carbon dioxide from the purified gas in the atmosphere, but dried carbon dioxide is imprinted in pre-prepared wells belonging to the company. This also contributes to the reduction of the greenhouse effect, which is a common phenomenon in gas processing processes. The Elemir plant is the first and only HiPACT plant in Europe, while in the world this technology is still only applied in Japan, and NIS has thus confirmed itself as a pioneer in the application of state-of-the-art technologies both in Serbia and in Europe. The implementation of this project allows NIS to attain a twofold result. On the one side, a substantial enhancement in the quality of domestic natural gas and in the production volume can be achieved, while the environmentally friendly production points to NIS as to a socially responsible company which takes care of its environment, on the other hand.

\section{Conclusion}

Being a leader in business means being a leader in innovation, investment and care for people and the environment. There are different types of innovations in the literature which could be recognized in the business and technological development of NIS. Product technological innovation represents an outcome of production and commercialization of either new products/services or improved products/services, while process technological innovation corresponds to the use or adoption of a new production process or an improved production process. Considering the NIS company, there is not only a visible trend of improving already existing products and processes, but also a trend of introducing brand new product and process technologies. 
In the case study analysis there are three main innovations of NIS: Bottom of the Barrel Plant, cogeneration (mini-power plants and TE-TO Pančevo) and Amine Plant. Owing to these technological innovations, NIS has become one of the largest and the most successful companies in this region and can be the role model for other oil and gas companies. As the only company in Serbia engaged in the exploration and production of oil and gas in Serbia, NIS is persistently investing in new technologies and new production capacities, which enable the growth of the company, and better quality of the environment and people. Generally, it is desirable to introduce innovations which can contribute to higher profitability and technological competitiveness.

The petroleum industry is specific for many reasons, such as high costs of equipment, fierce competition on the market, unstable prices, regulations etc. Companies should pay attention to important facts during the decision-making process, because wrong decisions can be too costly, especially for smaller companies. It is risky, but still necessary for all the companies in this industry if they want to retain their share of the market and stay profitable. Only by following contemporary technological trends in this industry, a company can make progress and penetrate the market.

Technical capabilities and the needs of the market should be taken into account while deciding on introducing new or improved technologies in the company. As there is a there is a strong correlation between market performance and new products (Tid, Bessant \& Pavitt, 1997), these technological innovations contribute not only to NIS, but also to the government, the environment and people. So, technological development can lead to higher satisfaction of numerous stakeholders. There are different benefits in the form of improved financial and environmental performance and effects. The business of oil and gas companies is thought to be in the collision with the environment, global emission restraint and so on, but this case shows the opposite. The main limitation of the research is that the case study is based only on one company, so results cannot be generalized. In future research, more companies should be included to get an overall picture of the petroleum system and applied innovations.

Technological trends currently present in NIS lead to better financial performance and additional opportunities for gaining a superior competitive advantage. Also, technological innovations enhanced the company's efficiency, reduced the costs of production, improved already existing products and processes, and many other effects are expected to be realized. NIS provides oil, gas and energy stability in the region with the help of the latest technological innovations. Furthermore, these technological innovations are aligned with the contemporary world trends, and they represent eco-innovations which reduce the negative impact on the environment and people. To increase the efficiency of the business, it would be desirable if NIS could continue with the diversification of its business portfolio. It would ensure more benefits for all stakeholders, such as society, global political organizations, shareholders etc. Oil and gas companies should strive to develop alternative sources of energy.

\section{References}

Diaconu, M. (2011). Technological innovation: Concept, process, typology and implication in the economy. Theoretical and Applied Economics, 18(10), 127-144. 
Drucker, P. F. (1985). Innovation and entrepreneurship: Practice and principles. New York: Harper \& Row.

Hamel, J., Dufour, S., \& Fortin, D. (1993). Case study methods. Newbury Park: Sage Publications.

Levi-Jakšić, M., Marinković, S., \& Obradović, J. (2005). Menadžment inovacija i tehnološkog razvoja. Belgrade: Faculty of Organizational Sciences.

Mentz, J.C. (1999). Developing a competence audit for technological innovation. Unpublished master's thesis, University of Pretoria, Pretoria, South Africa.

OECD Eurostat (2005). Oslo Manual: Guidelines for collecting and interpreting innovation data. 3rd ed., Paris: Organization for economic co-operation and development publishing.

Pennings, P., Keman, H., \& Kleinnijenhuis, J. (2006). Doing research in political science. 2nd ed. London: SAGE Publishing.

Schumpeter, J.A. (1934). The theory of economic development: An inquiry into profits, capital, credits, interest, and the business cycle. Piscataway: Transaction Publishers.

Stošić, B. (2013). Menadžment inovacija - Inovacioni projekti, modeli i metodi. Belgrade: Faculty of Organizational Sciences.

Tellis, W. (1997). Introduction to case study. The Qualitative Report, 3(2), 1-14.

Tidd, J., Bessant, J., \& Pavitt, K. (1997). Managing innovation: integrating technological, market and organizational change. Trowbridge, Wiltshire: Redwood Books.

Trott, P. (2017). Innovation management and new product development. 6th ed. London: Pearson Education.

Welsh, I., Lyons, C.M. (2001). Evidence-based care and the case for intuition and tacit knowledge in clinical assessment and decision making in mental health nursing practice: an empirical contribution to the debate. Journal of Psychiatric \& Mental Health Nursing, 8(4), 299-305.

Yin, R.K. (2009). Case study research: design and methods. 4th ed. London: SAGE Publishing.

https://www.nis.eu 